CURRENT RESEARCH JOURNAL OF PHILOLOGICAL SCIENCES

(ISSN -2767-3758)

VOLUME 03 ISSUE 01 Pages: 101-107

SJIF IMPACT FACTOR (2021: 5 . 823)

OCLC - 1242423883 METADATA IF - 6.925

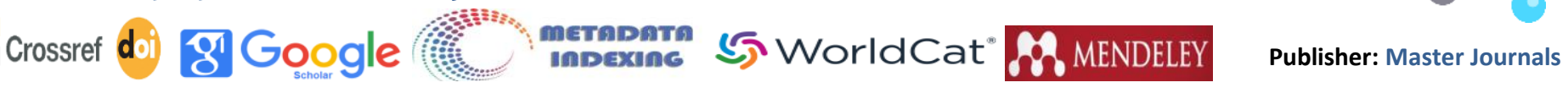

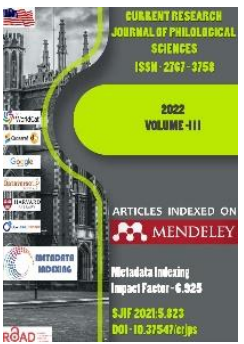

Journal Website: https://masterjournals. com/index.php/crips

Copyright: Original content from this work may be used under the terms of the creative commons attributes 4.0 licence.
Research Article

\section{MODULAR TECHNOLOGY OF TEACHING ENGINEERING COMPUTER GRAPHICS TO FUTURE TEACHERS DRAWING}

\author{
Submission Date: January 11, 2022, Accepted Date: January 21, 2022, \\ Published Date: January 31, 2022 \\ Crossref doi: https://doi.org/10.37547/philological-crjps-03-01-17 \\ Dilshodbekov Shoxboz Dilshodbek Ugli \\ Associate Professor, Phd, Tashkent State Pedagogical University Named After Nizami, Uzbekistan \\ Abduazizov Bunyodbek Islomjon Ugli
}

Master, Tashkent State Pedagogical University Named After Nizami, Uzbekistan

\title{
ABSTRACT
}

This article discusses the modular technology of teaching engineering computer graphics to future teachers of drawing.

\section{KEYWORDS}

Engineering computer graphics, modular technology, flat drawing, three-dimensional virtual model.

\section{INTRODUCTION}

Computer graphics engineering is a new science, which is a promising part of the graphics preparation unit. Engineering computer graphics is an educational science that includes elements of geometry and drawing. It is in the formative stage. The purpose of science is to formulate the ability of future specialists to perform drawings on a computer and read. The acquisition of knowledge from computer graphics becomes an important element of an engineer's professional activity.

The study of applied graphics systems is carried out at the user level. That is, the student learns only to use these graphics programs, and not to create them. The amount of theoretical knowledge in this case is minimal [1]. 


\section{CURRENT RESEARCH JOURNAL OF PHILOLOGICAL SCIENCES}

(ISSN -2767-3758)

VOLUME 03 ISSUE 01 Pages: 101-107

SJIF IMPACT FACTOR (2021: 5. 823)

OCLC - 1242423883 METADATA IF - 6.925

\section{Crossref

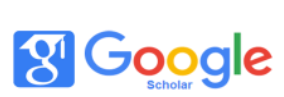

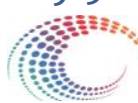

metapata

5. WorldCat ${ }^{*}$ भ̂े MENDELEY

Publisher: Master Journals

The study of computer graphics engineering begins at the third stage of the graphic educational course of pedagogical higher educational institutions. Having mastered the techniques of descriptive geometry and the rules of drawing with a pencil, future teachers will solve drawing problems based on modern graphic programs. Then future teachers will perform graphic tasks first manually, and then automatically (this will allow them to quickly understand the techniques of work and compare the quality of drawings) [2].

The use of computer-aided design (CAD) programs by students increases their interest in the information being studied, forms and deepens their theoretical knowledge, and also contributes to improving the efficiency and manufacturability of the learning process. The realization of knowledge (sequence, visualization, existence and differentiation) on the creation of three-dimensional models of complex shape when performing educational tasks is determined in further studies of the educational process and in subsequent creative activity [3].

Students perform drawings of various parts in an automated design system. The tasks are selected in such a way that they allow you to master both the computer graphics software product and the classical component of graphic activity. It is obvious that the performance of work using a personal computer contributes to the development of students' skills of independent learning activities.

We believe that at a time when the development of technologies and technologies is accelerating more and more, it is also worth developing a technology for the formation of knowledge and skills for its use. In our opinion, modular training in engineering computer graphics, due to the current demand, will give a positive result in the training of future drawing teachers.
The essence of modular training is that the student (student) works independently on the basis of the individual curriculum presented to him. It is the curriculum that should contain an action plan, a block of information, methodological recommendations for achieving learning outcomes. In these conditions, the educator performs the functions of control, counseling, coordination of actions for the assimilation of information [4].

In the modern theory and practice of modular training, two different approaches can be distinguished: the scientific-activity approach and the system-activity approach.

Within the framework of these approaches, a number of concepts for training specialists on a modular basis have been developed. All concepts are based on an activity-based approach, and from this point of view, the learning process becomes aimed at the consistent assimilation of the elements of professional activity by the student in accordance with the content of the modular educational program as a whole or within a specific subject.

Within the framework of different concepts, modular curricula will consist of different contents and structures, will be presented in documents of different forms, but they will all necessarily include the following three main components: a targeted content program; a bank of information presented from different angles; methodological recommendations for students.

\section{Principles of modular training}

1) modularity - selection of individual elements from the training content;

2) dynamism - achieving mobility (practicality) and efficiency of knowledge; 


\section{CURRENT RESEARCH JOURNAL OF PHILOLOGICAL SCIENCES}

(ISSN -2767-3758)

VOLUME 03 ISSUE 01 Pages: 101-107

SJIF IMPACT FACTOR (2021: 5. 823)

OCLC - 1242423883 METADATA IF - 6.925

3) flexibility - adaptation of the content of education and ways to achieve it in accordance with the individual needs of the student;

4) comprehensive methodological counselingensuring professionalism in the cognitive activity of the teacher and in pedagogical activity;

5) equality-ensuring business cooperation between the recipient of education and the teacher;

6) the principle of reliance on errors. This principle will be aimed at creating a situation of constant search for mistakes in the learning process, at developing didactic materials and tools aimed at forming the structure of premonition in the structure of the functional system of mental activity of students.

7) the principle of saving study time. This principle will be aimed at creating a reserve of study time for individual and independent work of students;

8) the principle of continuity. This principle implies a systematic approach to the development of curricula and programs to ensure that learning goals can be achieved. This ensures that the hours in the curriculum correspond to the objectives of the disciplines.

9) the principle of functionality: this principle means that modules are formed in accordance with the content of the specialist's activity;

10) the principle of system quantization. This principle is based on the requirements of the theory of information processing, the concept of pedagogical knowledge, the theory of the enlargement of didactic units.

11) the principle of motivation (arousing interest). The essence of this principle is to stimulate the educational and cognitive activity of the student. This is the basic rule.

12) the principle of modularity. This principle serves as the basis for individualization of learninglearning.
13) The principle of problemativeness. This principle makes it possible to increase the efficiency of mastering educational material due to problematic situations and the practical orientation of training.

14) the principle of cognitive visibility (observed with the naked eye). This principle follows from the psychological and pedagogical laws, according to which displays in training increase the productivity of assimilation only if they perform not only a pictorial task, but also a cognitive one.

Structure of the modular curriculum for engineering computer graphics

The modular training program should include:

1. Action Plan

2. Information block

3. Methodological recommendations for achieving learning outcomes

4. Control works

The following materials are prepared for each module:

1. Modular program with full coverage of the academic period;

2. Theoretical material for each module (lecture);

3. Educational and methodological handouts;

4. Individual tasks for each module;

5. List of educational and scientific literature;

6. Tasks for independent work on each module.

The development of a methodology for teaching engineering computer graphics should be carried out taking into account two main provisions underlying the design using computer technology. The first provision is based on a two-dimensional geometric model and the use of a computer as an electronic flagship, which significantly speeds up the design process and improves the quality of design 


\section{CURRENT RESEARCH JOURNAL OF PHILOLOGICAL SCIENCES}

(ISSN -2767-3758)

VOLUME 03 ISSUE 01 Pages: 101-107

SJIF IMPACT FACTOR (2021: 5. 823)

OCLC - 1242423883 METADATA IF - 6.925

documentation. The drawing, in this case, occupies a leading place and is a way of presenting a product containing information for solving geometric problems, as well as for manufacturing a product. The second provision provides for the construction of a spatial geometric model of the product, which is a more visual way of presenting the original and a more convenient tool for solving geometric problems of varying complexity. Knowledge of the technique of computer creation of a drawing and a geometric model of a design object is the most important link in the training of engineers of any specialty [5].

In the field of educational engineering and graphic activity, computer graphic images are usually obtained in two ways:

- in the first, the computer acts as a tool with which the future specialist creates the conceived object in various ways;

- in the second case, the student sets a certain algorithm to the machine, and he himself may not even assume what may result.

The first situation is possible if the student is prepared for professional engineering and graphic activity and is an experienced user of the CAD system used. However, its implementation requires serious theoretical and practical training of a future specialist. The second situation develops if the student is insufficiently prepared. Teachers in practice have to deal with both situations. Depending on the specific situation, there is a need to develop and use various information educational resources [6].

Considering the above, we consider it appropriate to teach the discipline of computer graphics engineering, dividing it into two main modules:

1. Making a flat drawing (2D);
2. Building a three-dimensional model (3D).

The basis of the design used at the Tashkent State Pedagogical University is the formation of a geometric model of the object - its drawing. There are twodimensional (2D) and three-dimensional (3D) geometric modeling technologies. With 2D technology, the development of an object is carried out by constructing and analyzing its flat images projections (Monge plots). 2D technologies are currently the main method of projection. The theoretical basis of 2D technology is descriptive geometry. Computer variants of 2D technology are common, in which a computer is used as an electronic flagship, allowing the designer to unload from routine graphic work. However, the essence of the projection method changes at the same time: the image is fixed through the medium of flat images - projections. According to $3 \mathrm{D}$ technology, geometric modeling is carried out on the basis of direct operation of spatial objects, and not their projections. This natural design option for humans has become really possible thanks to computer graphics, which makes it quite easy to control the creation of three-dimensional models and visually display them on the screen. Reproducing a spatial object, the computer performs many geometric modeling operations: builds intersection lines, sections and sections, any projections and much more. Thus, the intelligent unloading of the designer is carried out.

With the help of a computer, the student receives an image of a three-dimensional model on the screen. In real time, the simulated object can be rotated, moved and combined with other objects. Thanks to such powerful visualization, which transforms mathematical knowledge into computer pictures, students have the opportunity to observe, manipulate visual and geometric images, which contributes to the 


\section{CURRENT RESEARCH JOURNAL OF PHILOLOGICAL SCIENCES}

(ISSN -2767-3758)

VOLUME 03 ISSUE 01 Pages: 101-107

SJIF IMPACT FACTOR (2021: 5. 823)

OCLC - 1242423883 METADATA IF - 6.925

\section{soment

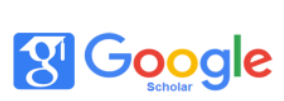

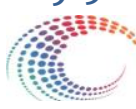

METDDETh

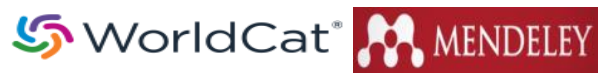

Publisher: Master Journals

intensification of the learning process, the birth of new ideas, heuristic discoveries, and, as a result, the formation of creative thinking.

\section{REFERENCES}

1. Русских Т.И. Формирование графической компетенции у будущих бакалавров техники и технологий. Дисс. кан. пед. наук. - Киров 2010. -164 c.

2. Верстаков Е. В. Особенности преподавания дисциплины «инженерная и компьютерная графика» в Волгоградском государственном университете. Вестник ВолГУ. Серия 6. Вып. 13. 2011-2012. - С. 89-92.

3. Дилшодбеков Ш.Д. “Автоматлаштирилган лойихалаш дастурларини ўқитиш методикаси. Монография., “LESSON PRESS” nashriyoti 2021, ISBN 978-9943-7710-2-4, bosma taboq 8,5

4. Абдуллаева Л.С., Самадова С.А. Модульное обучение // Наука. Мысль: электронный периодический журнал. 2014. №6. URL: https://cyberleninka.ru/article/n/modulnoeobuchenie (дата обращения: 11.01.2022).

5. Григоревский Л.Б. Разработка тематический классификаторов для повышения качества изучения студентами начертательной геометрии и инженерной графики: Дис. ... канд. пед. наук : 13.00.02 .-М.: РГБ, 2005.

6. Пузанкова А. Б. Формирование профессиональных инженерно-графических компетенций студентов в процессе их обучения компьютерной графике (на примере специальностей машиностроительного профиля). Дис. Пед. наук. 13.00.08. Самара-2012. $190 \mathrm{c}$.

7. Shoxboz, D. (2019). THE ESSENCE OF TEACHING ENGINEERING COMPUTER GRAPHICS AS A GENERAL TECHNICAL DISCIPLINE. European
Journal of Research and Reflection in Educational Sciences Vol, 7(12).

8. Аширбаев, А. (2021). ЧИЗМАЧИлИК ТАЪЛИМИНИНГ УЗВИЙЛИГИНИ ТАЪМИНЛАШ ВА УНИ ТАКОМИЛЛАШТИРИШ МАСАЛАЛАРИ. ГРААЛЬ НАУКИ, (6), 434-439. https://doi.org/10.36074/grail-ofscience.25.06.2021.082

9. Аширбаев, А. (2021). Chizmalarga о 'Icham qo 'yishda yuzaga kelishi mumkin bo 'Igan tipik xatolar va ularning oldini olish omillari. Общество и инновации, 2(3), 7-15.

10. Dilshodbekov, S. (2018). Modern Graphic Programs Methodical Possibilities in Teaching Engineering Disciplines. Eastern European Scientific Journal, (6).

11. Дилшодбеков, Ш. А. (2021). MUHANDISLIK KOMPYUTER GRAFIKASI FANIDAN MUSTAQIL TA'LIMNI TASHKILLASHTIRISH USULI. ИННОВАЦИИ В ПЕААГОГИКЕ И ПСИХОЛОГИИ, 4(1).

12. Dilshodbekov, Shoxboz Dilshodbekovich (2021) "FOREIGN EXPERIENCE OF TEACHING ENGINEERING GRAPHIC DISCIPLINES BASED ON COMPUTER GRAPHICS," Scientific Bulletin of Namangan State University: Vol. 2: Iss.2, Article 79. Available at:

https://uzjournals.edu.uz/namdu/vol2/iss2/79

13. Jabbarov, R. (2021). Уникальное направление, вдохновленное творчеством Камолиддина Бехзода, великого миниатюриста Восточного Возрождения. Общество и инновации, 2(5/S), 59-67. https://doi.org/10.47689/2181-1415-vol2iss5/S-pp59-67

14. Malikov, K. G. (2020). Theory and practice of construction of axonomertic projects. European Journal of Research and Reflection in Educational Sciences Vol, 8(9). 


\section{CURRENT RESEARCH JOURNAL OF PHILOLOGICAL SCIENCES}

(ISSN -2767-3758)

VOLUME 03 ISSUE 01 Pages: 101-107

SJIF IMPACT FACTOR (2021: 5. 823)

OCLC - 1242423883 METADATA IF - 6.925

15. Gafurovich, M. K. (2021). Axonometry New Practical Graphical Methods For Determining System Parameters. Psychology and Education Journal, 58(2), 5710-5718.

16. Мирзалиев, 3. Э., Халимов, М. К., Маликов, К. Г., \& Абдухонов, Б. Х. (2017). Методика использования нового механизма для построения аксонометрических проекций. Молодой ученый, (8), 1-6.

17. Kozim, M., Zilola, F., \& Sanjarbek, S. (2019). DETERMINATION OF THE PARAMETERS OF THE DEFAULT ISOMETRIC VIEW USING METHOD OF RECTANGULAR AUXILIARY PROJECTION. European Journal of Research and Reflection in Educational Sciences Vol, 7(12).

18. Халимов, М. К., Ташимов, Н. Э., \& Маликов, К. Г. (2015). ЧИЗМАЧИЛИК ФАНИНИ ЎҚИТИШДА ДИДАКТИК ЎЙИНЛАРДАН ФОЙДАЛАНИШ МЕТОДИКАСИ. In СборникИ КонференциЙ НИЦ Социосфера (No. 51, pp. 118-121). Vedecko vydavatelske centrum Sociosfera-CZ sro.

19. Мурадов, Ш. К., Халимов, М. К., Мирзалиев, 3. Э., \& Рамазанова, Г. С. (2017). Определение параметров формы и положения кривых 2-го порядка. Молодой ученый, (7), 454-457.

20. Мирзалиев, 3. Э., Халимов, М. К., Маликов, К. Г., \& Абдухонов, Б. Х. (2017). Методика использования нового механизма для построения аксонометрических проекций. Молодой ученый, (8), 1-6.

21. Рустам Джаббаров (2021). Уникальное направление, вдохновленное творчеством Камолиддина Бехзода, великого миниатюриста Восточного Возрождения. Общество и инновации, 2 (5/S), 59-67. doi: 10.47689/2181-1415-vol2-iss5/S-pp59-67

22. Ravshanovich, J. R. (2021). Rangtasvir Taraqqiyotining Ustuvor Yo ‘Nalishlari. Бошқарув ва Этика Қоидалари онлайн илмий журнали, 1(6), 137-148.

23. Jabbarov R., \& Rasulov, M. (2021). FURTHER FORMATION OF STUDENTS' CREATIVE ABILITIES BY DRAWING LANDSCAPES IN PAINTING.

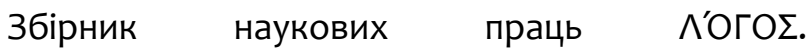
https://doi.org/10.36074/logos-30.04.2021.v2.09

24. Gulomova, N. (2021). "Uzatmalar" mavzusini o'qitishda "iSpring Quiz Maker" dasturidan foydalanib, talabalarga nostandart testlar orqali bilish faolligini faollashtirish. Жамият ва инновациялар, 2(5), 8-18. https://doi.org/10.47689/2181-1415-vol2-iss5-pp8-18

25. Valiev, A. (2021). ABOUT THE FEATURES OF THE PERSPECTIVE OF SIMPLE GEOMETRIC SHAPES AND PROBLEMS IN ITS TRAINING. Збірник наукових праць SCIENTIA. вилучено із https://ojs.ukrlogos.in.ua/index.php/scientia/articl e/view/10540

26. Валиев Аъзамжон Нематович. (2021). Об Особенностях Перспективы Простых Геометрических Фигур И Проблемах В Ее Обучении. CENTRAL ASIAN JOURNAL OF THEORETICAL \& APPLIED SCIENCES, 2(4), 54-61. Retrieved

27. Байдабеков, А. К., Мурадов, Ш. К., Адилов, П. А., \& Ташимов, Н. Э. Кривые второго порядкакак сечения поверхностей второго порядка по наперед заданным параметрам.

28. Халимов, М. К. Сравнение продуктивности учебной доски и проектора в преподавании предметов, входящих в цикл инженерной графики / М. К. Халимов, Р. Р. Жабборов, Б. Х. Абдуханов, А. А. Мансуров. - Текст : непосредственный // Молодой ученый. - 2018. — № 6 (192). — C. 203-205. URL:https://moluch.ru/archive/192/48066/

29. Xalimov, M., \& Farxodova, Z. (2021). DEVELOPING STUDENTS' CREATIVE ABILITIES BY MAKING 
CURRENT RESEARCH JOURNAL OF PHILOLOGICAL SCIENCES

(ISSN -2767-3758)

VOLUME 03 ISSUE 01 Pages: 101-107

SJIF IMPACT FACTOR (2021: 5. 823)

OCLC - 1242423883 METADATA IF - 6.925

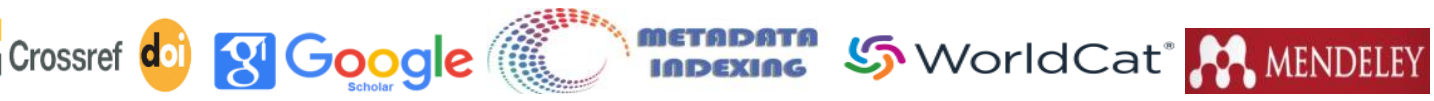

Publisher: Master Journals

PROBLEM SOLUTION SITUATION IN DRAWING

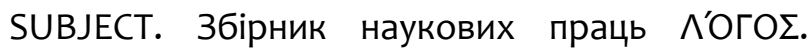

https://doi.org/10.36074/logos-30.04.2021.v2.62

30. Muslimov, S. N. (2019). THE ROLE OF PERSONALITY-ORIENTED EDUCATION IN THE DEVELOPMENT OF PROFESSIONALLY-GRAPHIC COMPETENCE OF FUTURE TEACHERS OF TECHNOLOGICAL SCIENCES. Scientific Bulletin of Namangan State University, 1(6), 442-445.

31. ХАЛИМОВ, М. К. (2019). ПРОФЕССИОНАЛЬНОЕ САМООПРЕДЕЛЕНИЕ УЧАЩИХСЯ В СОВРЕМЕННЫХ УСЛОВИЯХ. In Высшее и среднее профессиональное образование как основа профессиональной социализации обучающихся (рp. 118-124). 